\title{
AGAINST LOSS: CHOOSING NON-FICTION
}

\section{Michelle Morano}

I don't remember what my mother was wearing that night (though I'd guess navy blue polyester slacks), and I don't remember what my brother said to me when he poked his head around my half-closed bedroom door. I don't remember why I stayed in my room rather than going downstairs (perhaps the February wind coming through the propped-open front door?), and I especially don't remember where my father was during the commotion. All I remember is

Do you see how the list is taking over? It's starting to feed off itself, this list with a twist. Notice the negatives: I don't remember. That's a writing trick. When you're struggling to begin, you can find a word or a phrase to repeat a few times, then see what happens when you build sentences around it. And sometimes when you're really struggling, you can go for the negative space, for what isn't instead of what is. It's a simple exercise that helps you find your way into a memory, unless of course the sentences begin to seduce you. That's when you know you're in trouble - when the rhythm of your prose becomes so comfortable that the truth you're writing from takes on a new form.

For example: the real truth of my opening paragraph is that I remember quite a lot. OK, maybe not her clothes on that particular night. And maybe not precisely what my brother said, but the gist of it, sure: he said he'd talk to me tomorrow, he'd come and visit soon. Maybe he even asked if I'd visit him as well, but I wouldn't bet on that. I would write it, though, in a heartbeat, if the rhythm of my paragraph led me there. And in writing I might even have myself answer him. If I were writing a story, I'd probably give in to the temptation, have myself say what one ought to say to a little brother who looks scared and sad. Yes, I'll see you tomorrow. Of course. Don't worry. But in nonfiction, I'm tethered to the truth, to being honest about what I actually said, or probably said, or would have said if my brother really had asked if I'd visit him in his new home three miles away. We'll see. 
Honesty is a tricky policy when it comes to writing from memory. Here's another real truth: I do know why I was sitting in my bedroom instead of going downstairs while my mother was moving out. It's a simpler reason than the February wind blowing around the door, and less flattering. Spite. I wasn't giving her the satisfaction. I could have broken her heart if I'd milled about with a long face, and I might even have gotten her to change her mind and send away the large van idling in the driveway. But what good would that have done any of us? Then, as now, I struggled with the opposing emotions of a situation I couldn't change. And now, unlike then, I drift away from the simple facts, lead myself back, struggle constantly with what I want to call the truth.

For example: My father. He was sitting at the kitchen table, wearing jeans and a white tee-shirt, a can of Schaeffer open in front of him. All right, I couldn't see him from my bedroom, but I could hear him, his deep voice calling out now and again, "Don't you touch the rocking chair, Rita, I picked it out in Montgomery Ward's last August, it belongs to me!' He wasn't giving her the satisfaction either.

Ah, a parallel. That's another writing trick. The father sits at the kitchen table, defiant. Refusing to help, refusing even to get up and walk into the living room to make sure the moving men are taking only her things. And through the living room, up the stairs, across the hall, the daughter sits on her bed, cutting pictures out of Tiger Beat magazine, equally defiant.

As readers we delight in parallels; as writers we see them everywhere, sometimes even where they don't truly exist. But is it really so bad to give in to the temptation, to ignore uncertainty for the sake of balance? In any number of my childhood memories, my father does sit at the kitchen table with a can of Schaeffer in front of him. Why not on this night? I could say I imagine he sat... but I'd prefer to tell you outright what I think I know. So let's say the father really did sit in the kitchen and the daughter really did sit on her bed, and they both felt defiant. That still leaves room for complicated emotional truths. His wife is leaving him, right this very moment, and taking his son. She's not taking his daughter, though, and Christ Almighty, what's he supposed to do with her? She's twelve, looks seventeen, rolls her eyes in response to everything anybody says to her. Maybe his defiance is really paralysis. And dread.

Which is where the parallel ends. The defiant daughter isn't paralyzed; she's cutting around pictures of these Scottish rock stars, one after another, making a pile of images she'll later tape to the wall beside her bed at eye level. She's getting on with her work, as if it's not happening. As if pages of magazine print will absorb the echo that's already ringing from the empty bedroom next door, from the empty closet down the hall. She's cutting and cutting and wondering what they'll talk about at the dinner table, she and this man she doesn't really know, in spite of living with him her whole life. Is he going to take her school shopping? What about buying Kotex? Will her mother come back once a month and deliver a grocery bag 
full of supplies, or is she really on her own?

Third person's an amazing thing, its fictional distance so seductive. How much more appealing to write they than we, to sympathize with her than with $m e$. After all, she is a twelve-year-old child of divorcing parents, while $I$ am the adult child of divorced parents. Even I say, in response to the second statement, so what? And so it's tempting to go with the third person, to decide that the truth is better achieved by a different kind of inhabiting. In the third person, the writer can float - into the girl, into the brother, into the father, looking out from all their eyes, from all their perspectives. Pretending to know everything.

But if that's the plan, then I should go all the way, into the mother's head. I should slip into the mind of the woman in the (no need to equivocate now) blue polyester pants, the woman who's made the choice to leave, even though it may not feel like a choice. I should look around the house that is still, for a moment, half mine, then tell the boy to get in the car and tell the movers to wait just a second. I should rush back inside, up the stairs, across the hall, and open the door to the bedroom where she sits, defiant, methodically working scissors across a glossy page.

And then what?

Well. That's the dilemma. It's not the mother's perspective I'm worried about - I could do that to my own satisfaction, if not to hers. Because I do remember the look on her face, I do remember the pinched mouth, the way her lips always strain before tears well up, and I definitely do remember freezing my own face in response, letting it go blank. As if I didn't care about one single thing on the whole entire earth. And then her eyes narrowed in anger and I knew, right then, exactly what it would be like between us.

Do you see how the "I remember" fell away on that last sentence? "And then her eyes narrowed in anger and I knew, right then, exactly what it would be like between us." A statement of fact, unqualified by memory. But press me on this and I'll fold like an uncertain child. Well, I think she was angry, I think I remember that her face looked like it. And if you press some more - do I really remember thinking that things would go a certain way between us in the future? Yes. The scene and the realization are there in my memory. But it's possible that I added the realization later, while reflecting on the scene as an adult. Maybe it just feels like memory now. Maybe what I really thought at the time was that if I stayed mad at her for a few days, she'd see how things might go between us in the future if she wasn't careful. If she didn't do something to fix this business of moving out and taking my brother and leaving me behind, even though I insisted every day that I didn't want to go.

This is the danger of nonfiction writing. What's true? When can memory be trusted? Spend half a day absorbed in your sentence structures, and you'll start to wish things had gone differently, just for the sake of your prose. You'll start to see the glorious design, not in what happened but in 
what might have, almost, could have, maybe even now that you really think about it did happen. Because the more you think about it, the cloudier the memory becomes, and the more varied its possibilities.

Which brings us back to the third person. I could choose third person and call my experience a story and in that way let myself off the hook for all the uncertainty. I could sidestep memory's false integrity altogether and just admit to using my imagination. And why not? Why not write autobiographical fiction and save us the trouble (and embarrassment) of knowing which parts are true?

Perhaps because of this: to write my scene in third person, in fiction, is to give rise to a new temptation, the temptation to fix. I'd never let the scene stop with the mother's eyes narrowing in anger and the daughter knowing what things will be like between them from now on. In nonfiction, that's the emotional core I want to get to, the "hot coal," as Philip Lopate says, that all the remembered details fan. But in fiction, while I could invent a scene and delight in its ending on a down note, I know that in an autobiographical short story I'd want to fix the real-life material. Because after all these years, I still want too badly for things to turn out another way.

So in fiction, in third person, the mother would know how to read her daughter's face, would understand that the daughter is trying to make her angry, because anger is easier to deal with than almost anything else. The mother would know this in a story because $I$ know it, and instead of pinching her mouth and shaking her head and turning to leave - the most definitive leaving of all — she would push the door open. She would walk into the room and sit down on the bed and wait until the girl looked her in the eye, and then maybe she'd say something, or maybe not, and the story would end with silence. In third person, which both would and would not feel true, just as first person often does and does not feel true, the mother and the girl would sit suspended on the bed. And there would be the possibility that things would change between them irrevocably, but there would also be the possibility that they would not. And that second possibility would offer just enough hope for my satisfaction.

But let's think for a moment about what would be lost, because it's against loss that a writer may choose nonfiction, even with all the troublesome business of creating truth from memory. In the fictional version of my scene, there is much that you would not see. The six paces the mother takes between the bedroom and the staircase, for example, and the slow creaking of her weight down fifteen steps, and most importantly, the hollow closing of the front door, its echo reverberating through the floors and the walls and the roof, traveling up the stairs and across the hall to settle, finally, around me. 